\title{
RELIGIÃO E CULTURA PERIFÉRICAS: A REPRESENTAÇÃO DO ISLAMISMO NA CLASSIFICAÇÃO DECIMAL DE DEWEY
}

\author{
Marcos Luiz Cavalcanti de Miranda ${ }^{1}$ \\ Universidade Federal do Estado do Rio de Janeiro
}

Fabio Gomes da Silva

\begin{abstract}
Resumo
Analisa a representação de informações referentes à identidade e a religião islâmica no esquema de classificação bibli-ográfica mais utilizado do mundo. Investiga a existência de desvios na representação de assuntos referentes a culturas não alinhadas à cultura ocidental na $23^{a}$ edição da Classificação Decimal de Dewey (CDD23). Conceitua Organização do Conhecimento em sentido restrito como organização das informações em registros bibliográficos e, em sentido amplo, como a organização social do trabalho mental. Define Sistemas de Organização do Conhecimento, enquanto sistemas conceituais atuantes como tipos de representação do conhecimento sendo frutos da organização do conhe-cimento. Aborda a construção do conceito de Islamismo no Ocidente considerando as transformações de sentido mo-duladas pelo contexto sociocultural, conferindo ao Islã a imagem da violência. Define Religião segundo Durkheim como sistema unificado de crenças e de práticas relativo a coisas sagradas; e segundo Hans Mol como a identidade sacralizada. Aponta que a parcialidade na organização do conhecimento permite que documentos relativos à cultura e à identidade de grupos sociais não alinhados jamais sejam recuperados. Objetiva identificar como os assuntos referen-tes a culturas não alinhadas com o ocidente estão organizados; verificar a influência do contexto sociocultural na representação e recuperação da informação em bases de dados de culturas diversas; analisar o Islamismo e suas rela-ções conceituais na CDD. Para alcançar os objetivos propostos realizamos estudosna CDD23 segundo a metodologia de Miranda (2009), pesquisa bibliografica em bases de dados de diferentes culturas com ênfase nas influências do contexto sociocultural na produção cientifica pertinente a cultura Islâmica. Os resultados do estudo da representação do Islamismo na CDD23 demonstaram a existência de desvios (biases) de representação históricas da CDD, evidenci-ados tanto na seleção terminológica quanto em sua estrutura conceitual. Os resultados do levantamento bibliográfico nas bases de dados demonstram uma produção cientifica sobre assuntos referentes a cultura e identidade muçulmana numerosa e diversificada nas bases de dados de natureza global (DOAJ) e não ocidental (AJOL) e uma baixa produção na base de dados ocidental (Scielo). Reitera a necessidade da conduta ética por parte do profissional na classificação de assuntos não alinhadas a cultura ocidental.
\end{abstract}

Palavras-chave: Organização do Conhecimento. Sistemas de Organização do Conhecimento. Desvios. Representação do Conhecimen-to. Identidade. Islamismo.

\section{PERIPHERAL RELIGION AND CULTURE: A REPRESENTATION OF ISLAMISM IN DEWEY'S DECIMAL CLASSIFICATION}

\begin{abstract}
Examines the knowledge representation concerning the identity and the Islamic religion in the bibliographical classifica-tion schemes used in the world. Investigates the existence of deviations in the representation of subjects pertaining to cultures not aligned to Western culture in the 23rd. Dewey Decimal Classification Edition. Conceptualizes Knowledge Organization in strict sense as organization of information in bibliographic records and, in a broad sense, as the as the social organization of mental work. Defines Knowledge Organization Systems
\end{abstract}

\footnotetext{
${ }^{1}$ Bacharel em Biblioteconomia e Documentação pela Universidade Federal Fluminense (1989), Mestre (1997) e Doutor (2005) em Ciência da Informação pela Universidade Federal do Rio de Janeiro em Convênio com o Instituto Brasileiro de Informação em Ciência e Tecnologia. Atualmente é Diretor de Avaliação e Informações Institucionais da Pró-Reitoria de Planejamento, Procurador Educacional Institucional/Pesquisador Institucional e Professor Associado da Universidade Federal do Estado do Rio de Janeiro (UNIRIO).
} 
(KOS), while conceptual systems acting as types of knowledge representation being a result of the process of knowledge organization. Discusses the construc-tion of the concept of Islam in the West whereas the transformations of meaning modulated by the sociocultural con-text, giving Islam the image of violence. Defines Religion according to Durkheim as unified system of beliefs and prac-tices relative to sacred things; and according to Hans Mol as the identity enshrined. Performs study of DDC23 referred to according to the methodology of Miranda (2009) and bibliographic search in databases of different cultures with an emphasis on the socio-cultural influences of context in scientific production pertaining to Islamic culture. The results of the study of the classification schemes demonstrate the existence of representation's historical deviations of the DDDC23, evidenced both in the selection of terminology in your conceptual framework; and biases of corrections representation by classificatory approach of the the Universal Decimal Classification. The results of the bibliographic survey in the databases demonstrate a scientific production on subjects referring to numerous and diverse Muslim culture and identity in the global (DOAJ) and non-Western (AJOL) databases and a low Production in the Western Da-tabase (Scielo). It reiterates the necessity of ethical conduct by the professional in the classification of Subjects not aligned to Western culture.

Keywords: Organization and Representation of Knowledge. Knowledge Organization Systems. Bias in the representation. Identity. Islam.

\section{INTRODUÇÃO}

A agenda de pesquisa no âmbito da organização do conhecimento tem privilegiado estudos e pesquisas acerca de temáticas que envolvem questões filosóficas, sócio-políticas, éticas, culturais e tecnológicas no que se refere à representação, armazenamento e disseminação do conhecimento produzido, de maneira a tornar patente as práticas de informação que são, práticas sociais por excelência, envolvendo atores que desempenham distintos papéis no ciclo de apreensão, produção e uso do conhecimento para atender e satisfazer as mais diversas necessidades de informação para dar conta das suas atividades pessoais e profissionais na sociedade contemporânea.

A filosofia como empreendimento racional é e continua sendo a busca da verdade. Este esforço é basicamente centrado no homem e suas atividades. Este homem como um animal racional é um produto da cultura e isso ressalta a relação continuada entre cultura e filosofia. Essa correlação e a inevitabilidade da cultura na codificação e na existência da filosofia precipitaram o ímpeto e o movimento de alguns acadêmicos africanos olhar para sua própria cultura para angariar e galvanizar a filosofia nela latente.

O presente artigo trata da organização e representação do conhecimento sobre o Islamismo na Classificação Decimal de Dewey (CDD). A CDD caracteriza-se como um Sistema de Organização do Conhecimento (SOC) do tipo esquema de classificação bibliográfica, o qual é amplamente utilizado em unidades de informação, como bibliotecas e bases de dados para organizar o conhecimento registrado, com vistas à recuperação da informação. 
Organizar o conhecimento em unidades de informação envolve condicionantes filosóficas e culturais atuantes nas diversas fases da produção do conhecimento, na elaboração de SOC, na representação da informação contidas em documentos nos mais diversos ambientes de informação e nas necessidades de informação do usuário. Assim, os atores da produção científica, orientados ao contexto sociocultural, têm suas decisões influenciadas pela escala de valores aos quais tiveram contato. Desta forma, o contexto sociocultural influencia as decisões do autor na produção do conhecimento, as decisões do classificacionista na criação de SOC, na classificação de documentos por parte do classificador e as necessidades, demandas e desejos de informação do usuário.

Os esquemas de classificação mais utilizados na atualidade são frutos de nossa cultura ocidental, o que lhes confere uma visão muitas vezes deturpada de assuntos externos ao nosso contexto sociocultural. Neste sentido, a parcialidade na organização do conhecimento permite que documentos relativos à cultura e à identidade de grupos sociais não alinhados jamais sejam recuperados. Desta forma, biases na classificação repercutem o discurso discriminatório vigente na sociedade, fazendo com que o discurso de grupos em situação de minoria social seja silenciado. No caso da classificação de religiões, o reconhecido viés à filosofia, cultura e religiões ocidentais influencia tanto a terminologia quanto a estrutura destes esquemas de classificação, denotando a visão da cultura hegemônica sobre assuntos referentes a grupos em condição de minoria social.

Os objetivos desta pesquisa são identificar nos esquemas de classificação como os assuntos referentes a culturas não alinhadas com o ocidente estão organizados; verificar a influência do contexto sociocultural na representação e recuperação da informação em bases de dados de culturas diversas; analisar o "ISLAMISMO" e suas relações conceituais na CDD; verificar se a sua classificação reflete a representatividade da comunidade islâmica no mundo.

Para alcançar os objetivos propostos realizamos estudos na CDD23 segundo a metodologia de Miranda (2009), pesquisa bibliográfica em bases de dados de diferentes culturas com ênfase nas influências do contexto sociocultural na produção cientifica pertinente a cultura Islâmica. Os resultados do estudo da representação do Islamismo na CDD23 demonstraram a existência de desvios (biases) de representação históricas da CDD, evidenciados tanto na seleção terminológica quanto em sua estrutura conceitual. Os resultados do levantamento bibliográfico nas bases de dados demonstram uma produção cientifica sobre assuntos referentes a cultura e identidade muçulmana numerosa e diversificada nas bases de dados de natureza global (DOAJ) e não ocidental (AJOL) e uma baixa produção na base de dados ocidental 
(Scielo). Reitera a necessidade da conduta ética por parte do profissional na classificação de assuntos não alinhadas a cultura ocidental.

A metodologia utilizada neste estudo releva a metodologia de Miranda (2009), considerando a análise e estudo do esquema de classificação bibliográfica orientada à recuperação de classes e categorias temáticas relativos à Religião Islâmica; a identificação e extração dos segmentos temáticos da CDD23, relacionado ao conhecimento e cultura islâmicos; levantamento bibliográfico sobre o conhecimento muçulmano de forma a identificar a terminologia referente a cultura islâmica, bem como usos e sentidos do vocabulário utilizados pela comunidade e avaliação da estrutura conceitual/classificatória observando sua ordenação lógica; usos e sentidos de vocabulário; detalhamento dos assuntos.

A análise da CDD23 observou como critérios: a representação do assunto Religião; a estruturação conceitual do Islamismo na Classe 200 Religião verificando: a ordenação lógica, usos e sentidos de vocabulário e detalhamento de assuntos; e as relações entre os termos que refletem a representatividade da comunidade islâmica no mundo.

Como critério de seleção terminológica, foram considerados apenas termos tópicos, sendo termos complexos utilizáveis como exemplos de notações da CDD23.

\section{ORGANIZAÇÃO E REPRESENTAÇÃO DO CONHECIMENTO}

O termo Organização do Conhecimento, oriundo do campo da Biblioteconomia, foi inicialmente utilizado por Henry Evelyn Bliss, inclusive por ele concebido como designativo de um campo autônomo no sistema das ciências (DAHLBERG, 1995, p. 10).

Dahlberg utiliza a expressão Organização e Representação do Conhecimento, definindo como a "ciência que ordena a estruturação e sistematização dos conceitos, de acordo com suas características, que podem ser definidas como elementos de herança do objeto, e a aplicação dos conceitos e classes dos conceitos ordenados pela indicação de valores, dos referentes conteúdos dos objetos ou assuntos” (DALBERG, 2006).

Segundo Hjorland (2014), “Organização do Conhecimento é classificar, definindo conceitos e determinando suas relações semânticas" (HJORLAND, 2013, p.169). Trata-se em sentido restrito da organização da informação em registros bibliográficos (HJORLAND, 2014, p. 174). Em sentido amplo é retratada como a "organização social do trabalho mental, ou seja, de como o conhecimento é socialmente organizado e como a realidade é socialmente organizada" (HJORLAND, 2003, p.169). Neste ponto, a OC, enquanto campo associado a classificação e indexação de documentos, sofre profundas influencias de teorias e paradigmas fundamentais aos quais o documento está associado. Mas é também, em si, um campo 
influenciado por diferentes paradigmas relacionados às teorias do conhecimento (HJORLAND, 2013, p.174).

Assim, reconhecemos dois tipos/formas de organização do conhecimento: a Organização do Conhecimento enquanto classificação intelectual do conhecimento e a OC como a organização Social do Conhecimento. Hjorland (2003) A organização intelectual do Conhecimento envolve uma organização do conhecimento em conceitos, sistemas conceituais e teorias. A organização social do conhecimento, por outro lado, é a organização do conhecimento em profissões, negócios e disciplinas. Neste sentido, disciplinas são representações do conhecimento utilizadas em sistemas sociais de organização do conhecimento. Em ambos os casos a Organização do Conhecimento é profundamente atrelada a uma teoria do conhecimento. Desta forma, a leitura de mundo do classificacionista é relacionada ou derivada de uma teoria, na qual tende a ser compartilhada publicamente por paradigmas. Por conseguinte, tal condição denota a necessidade do conhecimento do assunto por parte do classificador na atividade de representação da informação. Em outras palavras, o classificador deve desenvolver a habilidade crítica para lidar com diferentes teorias e seu impacto ideológico nos esquemas de classificação (HJORLAND, 2013, p.171).

Por outro lado, compreende-se que a atividade do indexador/classificador não é cercada de neutralidade, uma vez que o contexto filosófico, social, histórico e cultural influencia as condições da produção do conhecimento.

Com efeito, admite-se a impossibilidade de neutralidade nas atividades de representação do conhecimento, dado que o profissional classificador/indexador não se descola das suas concepções, suas visões de mundo e tampouco é capaz de simular o "desligamento" nem sequer momentâneo da sua consciência (ARBOIT, 2017, p. 162).

Deste modo, a análise da informação, atividade de reconhecida interferência por parte do classificador, é influenciada diretamente pela leitura que o profissional detém do documento, o que orienta as atividades de classificação e indexação a certa concepção de mundo.

\footnotetext{
Mesmo a leitura técnica dos documentos está inexoravelmente ligada a leitura que o profissional que representa o conhecimento faz dos seus contextos de produção e uso, além do constante e inevitável diálogo que sua consciência trava com o mundo. Nesse sentido, tanto os sistemas de classificação e indexação como as notações e demais índices atribuídos aos documentos são considerados resultado de escolhas entre posições levantadas em determinados domínios, temas ou assuntos. (ARBOIT, 2017, p.162).
}

Considerando a falta da neutralidade, oriunda das influencias do contexto sociocultural, observa-se a possibilidade de sérios desvios de representação, os quais são evidenciados nos produtos (resumos e índices) e instrumentos da OC (SOC). Neste sentido, os SOC são constituídos a partir de uma literatura relacionada a domínios de conhecimento. Neste caso, o 
classificacionista justifica decisões sobre seleção terminológica e estrutura conceitual nestes sistemas a partir de critérios estabelecidos por forma de garantias.

O termo garantia, enquanto aporte para tomada de decisão para a construção de SOC, foi utilizada pela primeira vez por Hulme, em 1901, ao apresentar os princípios de garantia literária.

\begin{abstract}
A concepção original de garantia literária se sustenta na ideia nuclear de que a literatura de um domínio deve ser a fonte para extração e validação da terminologia a ser incorporada em um sistema de classificação, ou em qualquer outro sistema de organização do conhecimento. Vista sob esse prisma, a documentação atua como catalisadora do processo pelo qual se passa do estado-da-arte de uma disciplina ou espaço temático até a sua reconfiguração sob a forma de uma estrutura conceptual destinada à classificação e à indexação de documentos e recursos de informação de qualquer natureza, com vista a sua recuperação em face de demandas concretas de usuários com distintos níveis de instrução e com variados interesses e necessidades de informação (BARITÉ,2010, p.124).
\end{abstract}

O princípio da Garantia Literária, sugere que a seleção dos termos para a elaboração de SOC deva ser baseada na realidade, ou seja, no conhecimento registrado de certa área ou domínio de conhecimento. Neste caso, um conjunto de publicações forneceria a terminologia de determinado domínio do conhecimento.

\footnotetext{
A lo largo del tiempo, se han propuesto otras alternativas, derivaciones o complementos de la garantía literaria: la garantía de usuario (Lancaster, 1977), la garantía académica, basada en el consenso de los especialistas (Bliss, 1939), la garantía organizacional (National Information Standards Organization, 2005), la garantía cultural (Lee, 1976), la garantía estructural (Kent et al., 1975; Mitchell, 2007), la garantía lógica (Fraser, 1978), la garantía fenomenológica (Ward, 2000), e incluso la garantía de género (Olson y Ward, 1998; Olson, 2003, 2007), entre otras que se mencionan ocasionalmente en la literatura (BARITÉ, 2011, p.4).
}

Uma das principais utilidades da garantia literária está no processo de validação na construção e atualizações de Esquemas de Classificação Bibliográfica tradicionais como a Classificação Decimal de Dewey. Para Barité (2011). As aplicações possíveis da garantia literária são: Teste de justificação em esquemas de classificação bibliográfica; Respaldo para trabalho terminológico em conjunto; Teste de validação e justificação de terminologia pontual; Extensão de teste de justificação relativa as relações conceituais; Análise ou mapeamento de domínios; e como dispositivo de avaliação de linguagens e estruturas conceituais.Obviamente, a garantia literária sozinha não dá conta do conhecimento não registrado, oriundo de comunidades que compartilham os conhecimentos a partir da oralidade. A justificação para seleção terminológica deste tipo de conhecimento estaria sob a forma de uma garantia cultural.

Beghtol (2002) posiciona a garantia cultural em cada SOC baseada em assuntos e preocupações de certa cultura, qualquer cultura de determinado país, ou de uma maior ou menor unidade social (BEGHTOL, 2002). Neste sentido, cultura se refere a um conjunto de valores, 
crenças e conhecimentos próprios de um grupo social, em sua escala local, a distinção de uma cultura em respeito a outras e uma visão homogênea de pessoas e ideias, e as unidades sociais referidas a grupos étnicos, disciplinas acadêmicas, domínios da arte, facções políticas, religiões e/ou linguagens (BARITÉ, 2011).

Desta forma, A garantia cultural abarca tanto a literatura especifica de um recorte social, quanto às tradições locais de determinada cultura. Um ponto sensível do conceito de garantia cultural se refere a questão do princípio de hospitalidade presente em sistemas de organização universais, uma vez que mesmo as constantes transformações do conhecimento conferem a literatura mudanças advindas das transformações socioculturais. Neste sentido, o contexto, ao influenciar diretamente a produção do conhecimento, valida novas teorias e substitui antigos paradigmas. Por outro lado, a dinâmica do conhecimento também envolve a resistência ao novo, onde o antigo paradigma, ou modelo, apoia-se em uma estrutura própria, muitas vezes classificando novos conhecimentos como periféricos, não ciência, conhecimento inválido, popular ou inferior. Como exemplo, observa-se a dificuldade na classificação de religiões de matriz africana onde, apesar da riqueza cultural envolvida em suas práticas, ritos e lendas, não dispunha de notação especifica nos esquemas de classificação bibliográfica.

\subsection{Sistemas de Organização do Conhecimento}

A necessidade da recuperação de registros de informação demanda a construção de sistemas que permitam a organização e a representação de conceitos. Dahlberg (2006), considera os SOC em uma dupla aplicação, atuando na representação do conhecimento e na organização e representação dos assuntos dos documentos em um sistema.

Para Hodge (2000), o termo Sistema de Organização do conhecimento se refere a todos os tipos de esquemas concebidos para organizar a informação e promover a gestão do conhecimento. Incluem esquemas de classificação que organizam materiais de nível geral, cabeçalhos de assunto para prover acesso detalhado, e arquivos de autoridade para controle de versões variantes de informações chave. Incluem também esquemas menos tradicionais como redes semânticas e ontologias. Desta forma, o sistema de organização do conhecimento é o coração de cada biblioteca, museu ou arquivo (HODGE, 2000, p.3). Sua função primordial é organizar materiais para recuperação e gestão da informação, estabelecendo pontes entre o usuário da informação e o material onde a informação está registrada, de forma que o usuário não necessite de conhecimento prévio para recuperá-la. Um SOC funciona como guia para o usuário no processo do conhecimento e responde questões aos organizadores sobre o escopo da 
coleção e o que é necessário para fazê-la circular (HODGE, 2000, p.3). Possuem como características:

\begin{abstract}
A imposição de uma visão de mundo particular em sua coleção e itens relacionados. A caracterização da mesma entidade diferentes maneiras, dependendo da SOC utilizada deve haver semelhança suficiente entre o conceito expressado em um SOC e o objeto do mundo real ao qual conceito se refere, de forma que uma pessoa experiente possa aplicar o sistema com fiabilidade razoável. Da mesma forma, uma pessoa que procura o material relevante usando um SOC possa conseguir associar seu conceito a sua representação no Sistema (HODGE, 2000, p.3).
\end{abstract}

Para efeito desta pesquisa, apresentamos a Classificação Decimal de Dewey por se tratar do SOC mais utilizados no mundo.

\title{
2.2 Classificação Decimal de Dewey
}

A Classificação Decimal de Dewey (CDD) é um esquema de classificação bibliográfica enumerativo, cuja estrutura envolve conceitos de hierarquização de conceitos segundo disciplinas, representando a tradição científica de seu tempo.

A Classificação Decimal de Dewey é uma ferramenta de organização do conhecimento continuamente revisto para manter o ritmo com o conhecimento. $\mathrm{O}$ sistema é ampliado através da construção de notações, traduções interoperáveis, associação com categorias e mapeamento de outros esquemas de assunto (DCC 23, p.1).

Dewey desenvolveu a CDD em 1872 e sua primeira publicação, ainda anônima, se deu em 1876, sob título Classification and subject index for Cataloguing and Arranging the Books and Pamphlets of a Library, e este sistema classificatório só recebeu o nome de Classificação Decimal Dewey em sua $16^{a}$ edição. Dewey utilizava a metáfora da turba e do exército para justificar a classificação como forma de controle da informação.

Dewey via a informação como um amontoado caótico que necessitava de ordem. Ele usou uma grande variedade de metáforas para expor este argumento. Utilizando exemplos com empresas, organizações militares, religião e literatura, Dewey afirmava que a classificação, a grosso modo, é necessária para suplantar o caos (OLSON, 2011, p.4).

A principal influência da CDD advém da tradição filosófica ocidental, incorporando elementos de Aristóteles, Francis Bacon, Hegel e Harris, sendo este último apontado como criador do sistema que deu bases para construção da Classificação Decimal de Dewey. O Quadro 1 apresenta uma correlação entre as classes da CDD e as classes de outros esquemas de classificação. 


\begin{tabular}{|c|c|c|c|c|c|c|c|c|c|}
\hline \multirow[b]{2}{*}{ CDD } & \multicolumn{2}{|c|}{ 0 Generalidades } & \multirow[b]{2}{*}{$\begin{array}{l}300 \\
\text { Ciências } \\
\text { Sociais }\end{array}$} & \multirow[b]{2}{*}{$\begin{array}{l}400 \\
\text { Linguage } \\
\mathrm{m}\end{array}$} & \multirow[b]{2}{*}{$\begin{array}{l}500 \\
\text { Ciências } \\
\text { Naturais } \\
\& \\
\text { Matemát. }\end{array}$} & \multirow[b]{2}{*}{$\begin{array}{l}600 \\
\text { Tecnolog } \\
\text { ia }\end{array}$} & \multirow[b]{2}{*}{$\begin{array}{l}700 \\
\text { Artes }\end{array}$} & \multirow[b]{2}{*}{$\begin{array}{l}800 \\
\text { Literatura } \\
\text { \& Retórica }\end{array}$} & \multirow[b]{2}{*}{$\begin{array}{l}900 \\
\text { Geografia } \\
\text { \& História }\end{array}$} \\
\hline & $\begin{array}{l}100 \\
\text { Filos. } \\
\& \\
\text { Psicol. }\end{array}$ & $\begin{array}{l}200 \\
\text { Religião }\end{array}$ & & & & & & & \\
\hline $\begin{array}{c}\text { Baco } \\
\mathbf{n}\end{array}$ & \multicolumn{2}{|c|}{$\begin{array}{l}\text { Razão } \\
\text { Filosofia }\end{array}$} & & & & \multicolumn{2}{|c|}{$\begin{array}{l}\text { Imaginação } \\
\text { Poesia }\end{array}$} & & $\begin{array}{l}\text { Memória } \\
\text { História }\end{array}$ \\
\hline Hegel & \multicolumn{2}{|c|}{ Ideia (Begriff) } & \multicolumn{2}{|c|}{ Ideia Imperfeita } & & \multicolumn{2}{|c|}{ Essência (Wesen) } & & Ser $($ Sein $)$ \\
\hline $\begin{array}{c}\text { Harri } \\
\quad s\end{array}$ & \multicolumn{2}{|c|}{$\begin{array}{l}\text { Ciência } \\
\text { (Filosofia) }\end{array}$} & & & & \multicolumn{2}{|c|}{ Arte (Poesia) } & & História \\
\hline
\end{tabular}

Fonte: Olson (2011).

A CDD representa o conhecimento em dez classes principais que se subdividem em mais dez e, assim, sucessivamente. Dentro de cada uma delas existe subordinações. Estas subordinações são chamadas de hierarquia estrutural, em que "todos os temas (à exceção das dez classes principais) são subordinados e são parte de todos os temas mais abrangentes acima dele" (DEWEY, 2003). Logo, se uma pessoa deseja utilizar um nível de classificação mais específico, é imprescindível que este nível mais baixo tenha as características das generalidades que representam. Por exemplo: um livro que trate da religião católica deve estar dentro da classificação 280, pois é a subclasse que trata de Denominações Cristãs dentro da classe principal 200 - Religião.

Dewey elaborou a CDD com a premissa da sistematização e hierarquização do conhecimento, e é isto que faz da CDD um dos instrumentos de organização mais utilizados do mundo, embora seja considerada inferior teoricamente a outros SOC mais modernos que utilizam, mais livremente, letras e outros sinais para produzir notações mais curtas para conceitos de igual complexidade, como por exemplo, a Classificação Decimal Universal - CDU - desenvolvida pelos belgas Paul Otlet e Henri de La Fontaine, utilizando como base a CDD combinando os números básicos com outros sinais de pontuação (vírgula, dois pontos, parênteses, etc.). 


\subsection{A Informação, a Discriminação e o Direito a Expressão da Identidade}

Nesta seção apresentamos o direito a expressão a identidade, no sentido da disseminação de valores inerentes a cultura, credo, ideologias e práticas concernentes a identidade construída e professada de forma individual ou coletiva. O Pacto internacional sobre direitos civis e políticos trata, no artigo 26, sobre a questão da igualdade de direitos perante a lei, sendo os indivíduos resguardados de qualquer forma de discriminação, seja quanto a sua "raça, cor, sexo, língua, religião, opinião política ou de outra natureza, origem nacional ou social, situação econômica, nascimento ou qualquer outra situação" (BRASIL, 1992). Em seu artigo 27, versa sobre o direito das minorias étnicas, religiosas e linguísticas, sobre o direito à sua própria identidade cultural, da prática religiosa e da utilização de seu próprio idioma. Tais proposições são resultados de lutas históricas, sob objetivo de transformação do estágio vigente das questões das relações sociais de poder, as quais tornavam publicas as inquietações de comunidades com discurso não-alinhado com as ideias dominantes da sociedade.

Exemplos destes movimentos são as revoltas de escravos em Roma, as Beguine e
outros movimentos de mulheres no século XII, alguns dos quais desencadearam a caça
às bruxas e outras formas de repressão contra as mulheres, os movimentos/guerras
camponesas do século XVI na Alemanha, os conflitos históricos étnicos e nacionais
em todo o continente. É claro que, ao longo da história, na Ásia, no mundo árabe e na
expansão do Islã, assim como na África e na América Latina, múltiplas formas de
movimentos sociais se converteram em agentes de resistência e transformação social
(FRANK; FUENTES, 1989, p.19).

O direito à expressão cultural perpassa a questão da representatividade da diversidade cultural dentro da sociedade, abordando questões sobre a visibilidade destes grupos sociais e da disseminação de suas as ideias e valores. A composição de um grupo social subentende a existência de uma terminologia que o identifique como tal, ou de um escopo documental nos quais são registrados valores, hábitos e ideologias.

Por outro lado, as tensões advindas das relações de poder inferem também a construção de estruturas sob a intenção da manutenção de um status quo. Como exemplo observam-se questões sobre a discriminação advinda da construção da ideia de um único discurso válido, dispondo as demais ideias circulantes a um segundo plano. Tal disposição torna-se fonte para toda espécie de discursos de ódio, oriundos das tendências das instituições que lidam com a informação a disponibilizarem as mesmas segundo a perspectiva dominante.

Como exemplos de discriminação social advinda de um discurso majoritário, escolhemos a questão da propagação de conceitos inadequados sobre a religião islâmica, considerada pelo viés cristão ocidental, a heteronormatividade como fonte de preconceito sobre a comunidade LGBT, a disseminação da informação sob a perspectiva européia, como 
promoção do silencio e extinção dos discursos não alinhados com as ideias circulantes dentro da sociedade.

Direcionando a questão para o ramo da Organização do Conhecimento, a aplicação indiscriminada de conceitos que refletem uma única modalidade de discurso denota a replicação de conceitos discriminatórios, evidenciados nos sistemas de organização do conhecimento, o que destoa de um valor fundamental no que se refere à informação: a diversidade.

\begin{abstract}
A diversidade é declaradamente um valor fundamental para bibliotecas, embora seu enfoque continue a ser majoritariamente homogêneo. O caráter social é um valor central em termos do papel da biblioteca e sua a contribuição para melhorar ou resolver os problemas críticos da sociedade. A persistência e crescimento de desigualdades, combinada com políticas que não conseguem proteger os direitos e as oportunidades de minorias sociais, torna essencial priorizar a diversidade e justiça social nas bibliotecas (MIGLIOLI; SANTOS, 2017, p.139).
\end{abstract}

Neste caso, a promoção da diversidade social nas bibliotecas, seja em relação a seu público, assuntos ou colaboradores, constitui-se em ação para a garantia da cidadania. Abordando a questão da representatividade "bibliotecas podem exercer uma influência sobre a diversidade, ou sobre a falta dela, através de escolhas que fazem no cumprimento das missões primárias de recolher, preservar e fornecer acesso à informação" (MIGLIOLI; SANTOS, 2017, p.140). Milani e Guimarães (2011) apontam para a responsabilidade de uma conduta ética na representação de assuntos, abordando a necessidade da prevenção de biases como garantia do acesso e recuperação da informação.

Assim, as biases figuram como problemas éticos [.] que, no mais das vezes, levam à reflexão dos valores da área (Milani et al., 2009) na medida em que, [.], podem sinalizar para uma perda de "autonomia cultural" , o que causará danos ao acesso e recuperação da informação. Pode-se dizer, assim, que as biases não estão limitadas a descrições individuais; há biases relacionadas a "gênero, sexualidade, raça, idade, habilidade, etnicidade, linguagem e religião, [as quais] têm sido descritas com o limite para a representação da diversidade e para os efetivos serviços biblioteconômicos para populações diversas" (OLSON, 2002, p. 7).

A sub-representação de um grupo, aliado à construção e circulação de ideias negativas sobre determinada comunidade, torna-se fonte de condutas predatórias, sob o risco de privação de direitos de um determinado grupo social. Como exemplo, observa-se o senso comum construído no Ocidente acerca da Religião Islâmica que, na maioria das vezes, é associada à imagem de terrorismo, fanatismo religioso e violência, o que interfere diretamente nos direitos à expressão cultural e religiosa, visibilidade, livre acesso e circulação de seus adeptos.

Em pesquisa nos catálogos online da Biblioteca Nacional, constatou-se a existência de obras, cuja classificação terminológica reverberava tanto uma seleção inadequada para representação de assuntos específicos a religião Islâmica, quanto à existência de títulos que 
reverberam ora o desconhecimento da cultura muçulmana, ora a reprodução dos discursos de ódio aludidos a referida comunidade.

Como exemplo observa-se no Quadro 2 as relações entre os termos Jihad, Sharia, "Direito Muçulmano", "Fundamentalismo Islâmico" e Terrorismo no catalogo de Obras Gerais da Biblioteca Nacional, utilitária da CDD, tanto a não opção pelo termo reconhecido (Sharia), a associação para visão belicista do jihad, e a opção inadequada dos termos Islã (que se refere a religião islâmica, não seu viés ideológico), e terrorismo Islâmico (cuja notação envolve um viés religioso, e não político).

QUADRO 2 Relações entre os termos Sharia, Jihad, Fundamentalismo Islâmico e Terrorismo Islâmico no catálogo da Biblioteca Nacional

\begin{tabular}{|lcc|}
\hline TERMO TÓPICO & OBRA & NOTAÇÃO BN \\
Sharia & Derecho musulman & 340.59 \\
Jihad & A atual guerra islâmica: o terrorismo & 297.72 \\
Fundamentalismo & A doença do Islã & 320.550917671 \\
Islâmico & A crise do Islã: guerra santa e terror profano & 297.72 \\
Terrorismo Islâmico & & \\
\hline
\end{tabular}

Fonte: Biblioteca Nacional (2017).

Tal fato se repete nas notações do catalogo da Biblioteca Islâmica, na qual observa o viés político das relações entre o Jihad (Yihad), Fundamentalismo Islâmico e Terrorismo.

QUADRO 3 Relações entre os termos Sharia, Jihad, Fundamentalismo Islâmico e Terrorismo Islâmico no Catalogo da Biblioteca Islâmica AECID

\begin{tabular}{|c|c|c|}
\hline OBRA & NOTAÇÃO & $\begin{array}{l}\text { TERMOS } \\
\text { CORRELACIONADOS }\end{array}$ \\
\hline Eurojihad & $\begin{array}{l}28-769(4) \\
28-832(4)\end{array}$ & $\begin{array}{l}\text { Jihad (europeu) } \\
\text { Terrorismo Islâmico } \\
\text { Fundamentalismo Islâmico }\end{array}$ \\
\hline La yihad a nuestras portas & $\begin{array}{l}28-769(6-17) \\
28-832(6-17)\end{array}$ & $\begin{array}{l}\text { Fundamentalismo Islâmico - África } \\
\text { Terrorismo Islâmico - África }\end{array}$ \\
\hline $\begin{array}{l}\text { Citizen Islam: the Future of Muslim } \\
\text { integration in the West }\end{array}$ & $28: 32(4)$ & $\begin{array}{l}\text { Islã e política na Europa } \\
\text { Fundamentalismo Islâmico }\end{array}$ \\
\hline Islam: Vision critica & $\begin{array}{l}28 \\
28-832\end{array}$ & $\begin{array}{l}\text { Fundamentalismo Islâmico } \\
\text { Terrorismo - Aspectos religiosos }\end{array}$ \\
\hline
\end{tabular}

Fonte: AECID (2017)

Conforme visto, a ideia dominante na sociedade determina tanto a escolha dos termos para representar uma minoria, quanto da associação das ideias acerca de uma comunidade na sociedade. Neste exemplo, a ideia de fundamentalismo islâmico é recorrentemente ligada a Jihad e a atos terroristas. A ideia de guerra santa implícita na Jihad é comum também a outras religiões. Contudo, a ideia comum associada ao Islamismo constrói a ideia de que a Religião, bem como sua comunidade, adota a violência como regra. Neste sentido, torna-se necessária a, 
abordagem sobre conceitos relativos a Religião, Identidade e da composição da identidade Muçulmana. Observaremos a evolução conceitual do conceito Religião, da construção da identidade social e dos assuntos formadores da Identidade muçulmana, enquanto religião e ideologia.

\section{RELIGIÃO}

A presente seção visa compreender a formação do conceito de Religião enquanto resultado do processo de seleção filosófico-ideológica. Neste caso, o conceito religião é produto de um processo histórico, cujo sentido é modulado pelas várias transformações do saber, onde, influenciados por novas teorias e formas de pensamento, são frequentemente utilizados como forma de legitimação ideológica.

Neste sentido, o conhecimento sobre religião reflete o contexto sociocultural oriundo das diversas construções do seu conceito no Ocidente. Coutinho (2012) denota esta correlação ao associar a evolução do conceito de religião às transformações relativas ao desenvolvimento científico. Para o autor, o pensamento sobre religiões evolui de maneira continua através da história. Desta forma, o conceito sobre Religiões, evolui, morre e se re-fundamenta com bases em conceitos anteriores (COUTINHO, 2012).

\subsection{A Construção do Conceito de Religião no Ocidente}

Apresentamos aqui a construção do conceito religião no Ocidente, sobretudo a partir das transformações do termo religião e as consequentes transições de uso e sentido no Ocidente. O conceito ocidental da Religião, associado ao termo Religio, a princípio era relacionado ao cotidiano da sociedade romana na antiguidade. Segundo Azevedo (2010) "o termo religio, enquanto observância escrupulosa do rito, enquanto um zelo constante em relação aos deuses, dizia respeito aos atos do próprio cotidiano; cotidiano que, por sua vez, deveria se configurar por esse cuidado constante em relação aos deuses" (AZEVEDO, 2010, p. 92). Neste caso, o termo religio apresenta origem etimológica no termo relegere dos textos de Cícero, cujo "significado diz respeito a recolher-se, a fazer uma nova escolha, a retornar a uma síntese anterior para recompô-la" (AZEVEDO, 2010, p. 93).

Se por um lado o religio - relegere de Cícero atribuía o cuidado aos rituais inerentes ao cotidiano da cultura romana, autores cristãos como Lactancio, Agostinho e Tertuliano promovem uma ressignificação do termo seguindo uma intencionalidade filosófico-ideológica. 
A ressignificação envolvia uma delimitação acerca dos domínios do sagrado e do profano, de forma a contribuir com a clara definição daquilo que era "religião verdadeira" e do que era considerado como rito pagão, (AZEVEDO, 2010). Neste caso, a religio atribuía-se a origem etimológica religare, cujo sentido denotava o aspecto da dependência que caracterizava o culto cristão acerca da relação entre a Criatura e o Criador (AZEVEDO, 2010), resinificando o sentido do religio-relegere de Cícero, transformando a ideia do zelo escrupuloso aos rituais da religião romana politeísta para a noção Cristã de transcendência, da relação de dependência a um único Deus.

Assim, segundo Benveniste, o conceito de religio se modifica e se remodela de acordo com a ideia que o homem tem da sua relação com Deus: "para um cristão, o que caracteriza, em relação aos cultos pagãos, a nova fé, é o laço de piedade, essa dependência do fiel ao Deus, essa obrigação no sentido próprio da palavra", Ainda segundo Benveniste, essa ideia é completamente diferente da velha religio romana e prepara para a acepção moderna do termo (AZEVEDO, 2010, p. 95).

A criação das Humanidades delega novos sentidos à religião. Juntamente aos novos sentidos, emergem novos conceitos utilizados para explicar o fenômeno religioso de forma objetiva e racional. Desta forma, a religio cristã mais uma vez transforma-se, acrescentando a cosmovisão novos conceitos orientados ao contexto social a qual está inserido. Segundo Coutinho (2012) as diversas definições da religião no Ocidente contribuem na compreensão da natureza das manifestações religiosas. Segundo a visão subjetivista a religião é um "sistema composto por descrições do sagrado, respostas ao sentido do mundo e da vida (crenças), meios, sinais, experiências de ligação a esse sagrado (práticas), orientações normativas do comportamento (valores) e atores coletivos com regras e recursos próprios (coletividades)". Sobre suas funcionalidades, a religião "permite regular e justificar a conduta individual (normativa), providenciar coesão social (coesiva), consolar e aliviar (tranquilizante), fortificar a vontade (estimulante), dar sentido à vida (significante), possibilitar a experiência do sagrado (experiencial), crescer e amadurecer (maturativa), proporcionar identidade (identitária) e ministrar salvação (redentora)" (COUTINHO, 2012, p. 187).

Contudo, reconhece-se que o conceito de religião em sociedades não ocidentais são orientadas a uma cosmovisão divergente do Ocidente, onde a diversidade de religiosidades possui crenças e práticas específicas e igualmente influenciáveis pelo seu contexto sociocultural. Vale considerar que a escolha pelo termo não ocidental ao invés de Oriental, se dá pelo reconhecimento das religiões africanas como exemplo de cultura em que os termos Ocidental e Oriental não podem ser aplicados. 


\subsection{Religião em culturas não ocidentais}

A presente subseção trata da concepção da religião em culturas não ocidentais. Conforme citado na subseção anterior, o termo não Ocidental foi escolhido de forma a abranger tanto as culturas Orientais quanto as demais culturas cujos sentidos não permitem a conceituação Oriental ou Ocidental. Exemplos destas culturas são as religiosidades africanas e australianas que, apesar de sua localização geográfica apontarem para o Ocidente e Oriente respectivamente, sua cultura não é reconhecida como tal.

A construção do termo religião em sociedade não ocidental é orientada a existência de uma pluralidade, frutos de uma diversidade religiosa detentoras de diferentes concepções do sagrado. Que muitas vezes divergem do construto judaico cristão do Ocidente. Como exemplo, consideramos a sociedade nigeriana, cuja diversidade etnológica abarca a existência de cerca de 250 grupos étnicos com manifestações religiosas variam desde as cosmovisões monoteístas como as cristãs e muçulmanas, até as existências de variadas religiosidades tribais (IBEZIM, 2014).

Desta forma, em uma mesma cultura encontramos diferentes construções de sentido na construção de um conceito. Segundo Madu (2003, apud IBEZIM, 2014), a religião é "o reconhecimento do homem acerca da existência de poder ou poderes além de si mesmo, do conhecimento de quem ele é, como criador do universo, e como sustentador preservador e provedor deste universo. A religião elucida o relacionamento entre Deus e homem sobre quem é o criador e controlador deste universo" (MADU, 2003 apud IBEZIM, 2014, p.91). Já Ugwu (2003, apud IBEZIM, 2014) conceitua o sentido de sistema da religião, definindo-a enquanto um sistema de "fé e práticas envolvendo a relação entre a humanidade e o que é considerado como sagrado". Ibezim (2014) sintetiza a pluralidade religiosa Nigeriana concebendo a religião como "a conscientização do homem da existência de um ser (ou seres) espiritual que é maior do que ele. A este Ser é devotada sua total dependência a partir de cultos rituais e sacrifícios experimentados nos mais diversos grupos religiosos da Nigéria” (IBEZIM, 2014, p.91).

Conforme visto, o contexto sócio cultural modulou as definições de religião em sociedades ocidentais e não ocidentais. Nas sociedades ocidentais, prevalece a noção de transcendência advinda da cultura judaico cristã, onde a religião é "sistema mediador entre o homem e entidades superiores. [Revelando] o Deus único e transcendente" (COUTINHO, 2012, p. 91). Já nas sociedades orientais, "a transcendência não está presente, mas antes o panteísmo, um deus em tudo. Assim, a religião não é ligação a algo superior e transcendente, mas à própria natureza, a todos os seres vivos" (COUTINHO, 2012, p. 91). 
Ora, tal pluralidade de sentidos da religião infere a necessidade da busca de um sentido comum a várias religiosidades dispostas no Ocidente e no Oriente. Neste ponto, a próxima subseção trata da teoria da Religião de Durkheim enquanto modelo teórico que busca um distanciamento das concepções majoritariamente cristãs em favor do reconhecimento de uma pluralidade cultural e religiosa.

\title{
3.3 A Religião por Durkheim
}

Na teoria da religião de Durkheim, ao nos distanciarmos dos seus sentidos das concepções majoritariamente cristãs em prol do reconhecimento de uma pluralidade religiosa, buscamos uma concepção de religião de acordo com elementos comuns a toda manifestação religiosa.

Neste ponto, Guerriero (2012), afirma que a teoria da religião de Durkheim, traz uma importante contribuição sobre o assunto ao definir a dialética acerca do sagrado como elemento comum a todas as religiões. Durkheim representava uma ruptura ao pensamento vigente orientando sua pesquisa para além do pensamento cristianizado, orientando sua pesquisa às diversas manifestações religiosas na sociedade.

\begin{abstract}
Diz Durkheim que todas as crenças religiosas apresentam um mesmo caráter comum: supõem uma classificação das coisas, reais ou ideais, que os homens concebem, em duas classes, em dois gêneros opostos, designados geralmente por dois termos distintos que as palavras 'profano' e 'sagrado' traduzem bastante bem. A divisão do mundo em dois domínios que compreendem, um, tudo o que é sagrado, outro, tudo o que é profano, tal é o traço distintivo do pensamento religioso: as crenças, os mitos, os gnomos, as lendas, são representações ou sistemas de representações que exprimem a natureza das coisas sagradas, as virtudes e os poderes que lhes são atribuídos, sua história, suas relações mútuas e com as coisas profanas (DURKHEIM, 2000, p. 19-20 apud GUERRIERO, 2012, p.17.).
\end{abstract}

Para Durkheim a religião é um construto social com elementos que denotam a importância da manifestação coletiva da Religião na distinção entre o sagrado e o profano. (Durkheim, 2001, 46 apud COUTINHO, 2010, p. 178.). Neste caso, a coletividade atua como promotora de valores, práticas religiosas e ritos, atuante na construção de uma identidade em seus aderentes.

Durkheim confere a religião um conceito para além das religiões institucionalizadas, abarcando a diversidade de manifestações religiosas, individuais ou coletivas, existentes no mundo. Logo, a noção de sistema de crença e prática, aliada a uma comunidade moral única é aplicável tanto religiões institucionalizadas como Cristianismo, Islamismo quanto para as diversas religiosidades tribais espalhadas pelo globo. A figura 1 denota a distribuição das religiões majoritárias nos continentes. 
Figura 1. Religiões majoritárias no Mundo

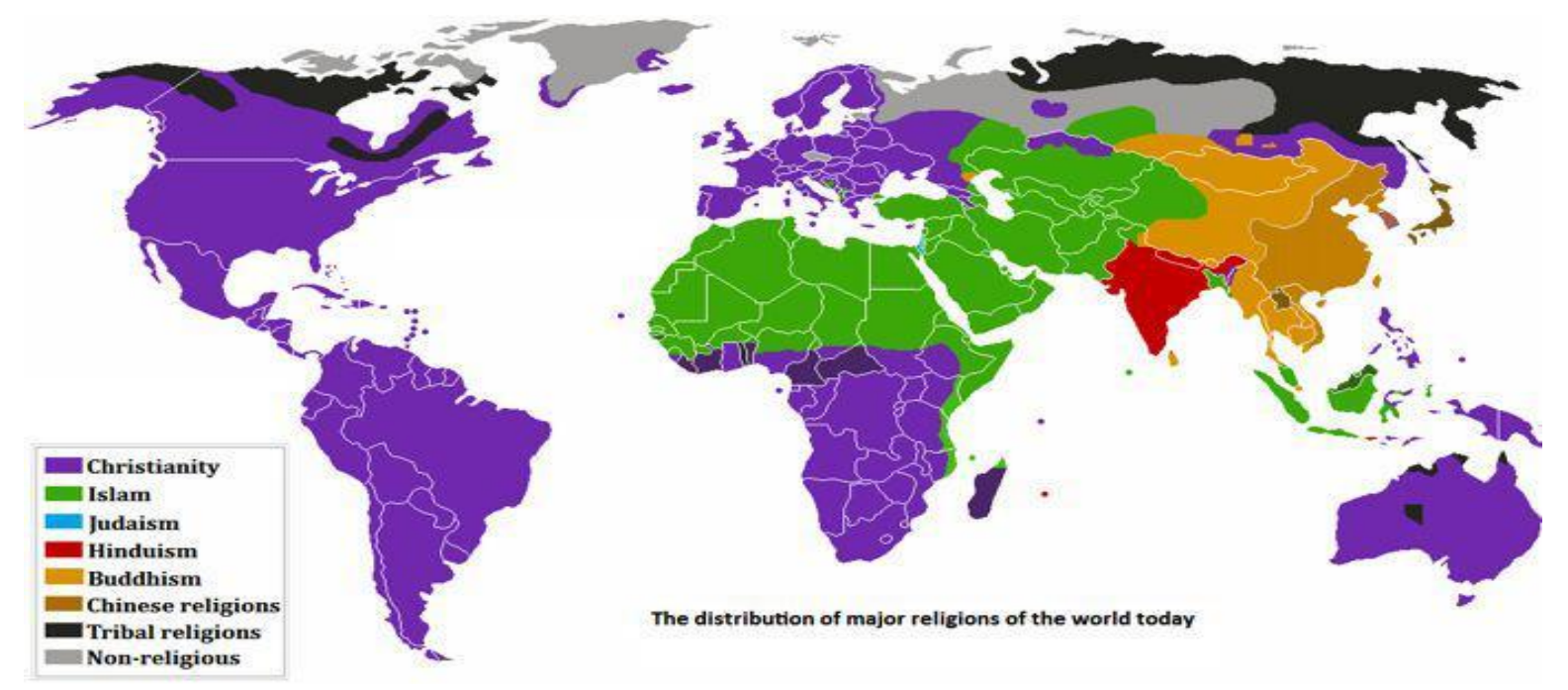

Fonte: Read the Spirit(2018).

Conforme visto em seção anterior, a religião é tema sensível no tocante a classificação. Falar de religião denota a necessidade de falar de conceitos e linguagens específicas, cujos sentidos envolvem uma forma de cultura e a expressão dos valores oriundos de uma identidade coletiva. Neste momento, torna-se necessário a conceituação de identidade religiosa enquanto forma de identidade coletiva. Relaciona-se conceitos como Identidade, enquanto construção social advinda das interações do indivíduo, ou um coletivo com o meio social, e Sacralização, apresentadada no Modelo de Identidade da Religião de Hans Mol, como salvaguarda na construção da identidade religiosa e Estigmatização como fruto da desconstrução de uma identidade social.

\subsection{Identidade religiosa}

A identidade segundo Berger e Luckmann (1976 apud BERLATTO, 2009) é um "fenômeno que deriva da dialética entre um indivíduo e a sociedade" (BERGER; LUCKMANN, 1976 apud BERLATTO, 2009, p.141). Em outras palavras, a identidade é o resultado de uma construção social onde indivíduos e coletividades se reconhecem e se auto reconhecem dentro de uma determinada estrutura social. Nesta dialética, "the processes of individual identity formation commonly influence and inform group identity formation, with the reverse being true as well" (AHJUM, 2013, p.159).

Para Haralambos and Holborn (2008 apud IBEZIM, 2014), a identidade é interna e externa. Interna na medida em que trata sobre auto-reconhecimento, sobre a forma com que nós pensamos acerca de nossa própria identidade, e externa ao considerar como o ambiente externo 
nos vê. Não se refere apenas a nossa própria impressão sobre nós mesmos, mas de nossas impressões sobre os outros e dos outros sobre nós. Portanto a identidade é o sentido que alguém tem sobre quem ele é, o que algo é, e o conjunto de impressões têm sobre os outros, alguém ou algo. Assim, identidade tem significado individualista e coletivo (HARAMBOLOS; HOLBORN, 2008 apud IBEZIM, 2014, p.91).

Mol (1979) acrescenta aos sentidos de identidade individual e de grupos (coletivas) a noção de identidade social. Afirma que todos estes níveis de identidade apresentam tendência a "unicidade" como fator de estabilidade, a inteireza/completude a partir da integração de características, ou ao fortalecimento de fronteiras em torno de uma única questão (MOL, 1979, p. 12).

Religion in general tends to promote the stabilization of individual and group identity by favouring the preservation of old content (in the form of doctrine, ritual, moral frameworks, role expectations, symbols and the like) offering individuals a basis for reconstructing their identities within a stable or very slowly changing universe of shared meaning. New content is typically assimilated and old content revised or interpreted only after cautious censorship (SEUL apud AHJUN, 2013, p.160).

Mol (1979) denota o conceito de sacralização como elemento estabilizador da identidade descrevendo-a como "o processo inevitável que protege a identidade quando ele está em perigo pelas desvantagens da adaptabilidade infinita dos sistemas de símbolos. Sacralização protege a identidade, um sistema de significado ou uma definição da realidade e modifica, obstrua ou (se necessário) legitima a mudança” (MOL, 1979, p. 16). Desta forma, compreendese que a identidade não é um objeto estático, mas sujeito às dinâmicas inerentes aos contextos sociais, e a sacralização como componente estabilizador de identidade. (MOL. 1979). A sacralização observa mecanismos como a objetificação, o comissionamento, os rituais e o mito.

\begin{abstract}
A objetificação atua como a projeção da ordem de um além onde é menos vulnerável a exceções, contradições e contingências -em outras palavras, um reino rarefeito onde principais contornos da ordem podem ser mantidos em face de luxações temporais, mas absorvente dessa ordem; o Comissionamento funciona como a ancoragem emocional nos vários focos de proliferação de identidade; os Rituais, enquanto ações repetitivas, articulações e movimentos com objetivo de evitar que objetos sacralizados se percam de vista; e o Mito como Integração das várias troncos em uma conta simbólica e coerente, de forma abreviada (MOL, 1979, p. 17).
\end{abstract}

Segundo Powell (2017) a identidade é "o nicho estável que o homem ocupa em um ambiente potencialmente caótico que, portanto, ele está preparado vigorosamente para defender" (MOL, 1976 apud POWELL, 2017, p.65). Ahjum (2013) afirma que a identidade, “individualmente ou coletivamente expressa, é um processo, ao invés de um estado fixo "(AHJUM, 2013, p. 159). Neste sentido, Berger e Luckman (1976 apud BERLATTO, 2009) afirmam que: 
[...] a formação e conservação das identidades são condicionadas por processos sociais determinados pelas estruturas sociais. Desse modo, a identidade social não diz respeito apenas aos indivíduos. Todo grupo apresenta uma identidade que está em conformidade a sua definição social que o situa no conjunto social. Assim, a identidade social é ao mesmo tempo inclusão - pois só fazem parte do grupo aqueles que são idênticos sob certo ponto de vista - e exclusão - visto que sob o mesmo ponto de vista são diferentes de outros (BERGER, LUCKMAN, 2009 apud BERLATTO, 2009, p. 142).

Tal dinâmica envolve relações de poder, onde grupos que possuem condição majoritária atuam tanto o reconhecimento de determinados grupos minoritários, quanto em sua estigmatização, em uma clara relação de dominação. Desta forma influenciam as ideias inerentes a indivíduos pertencentes a um grupo minoritário, sob a intenção da manutenção de um status quo.

Como exemplo de conflitos desta natureza, identificam-se as relações de dominação entre as etnias residentes nas províncias da Nigéria. Etnias em condição majoritária como Hausa-fulani, Iorubá e Igbo interferem no arcabouço cultural da região de tal forma que provocam o aculturamento das etnias em condição de minoria social (IBEZIM, 2014). Neste caso, observa-se o risco de uma sistemática extinção de uma identidade cultural religiosa a partir dos conflitos religiosos, do aculturamento dos grupos minoritários, do incentivo a endogamia religiosa, do etnocentrismo cultural e da secularização advinda do modernismo. Como consequência, observa-se a influência da situação relacional nas estratégias para a legitimação de uma identidade (IBEZIM, 2014).

De acordo com a situação relacional, a auto identidade que diz respeito à capacidade
de o indivíduo se nomear, terá maior ou menor legitimidade que a heteroidentidade
(refere-se à força dos atributos construídos pelos outros em relação ao indivíduo). Ou
seja, vai depender da relação de força entre os grupos de contato, que poderá ser uma
relação de força simbólica. A heteroidentidade traduzir-se-á pela estigmatização dos
grupos minoritários, numa situação de dominação caracterizada (BERLATTO, 2009).

No Ocidente encontramos na construção dos estereótipos das culturas periféricas em situação de minoria social e orientais outra evidência destas relações de poder. Para efeito de trabalho, consideraremos a construção do estereotipo do Muçulmano no Ocidente em contraposição aos valores que compõem a identidade muçulmana.

A próxima seção trata da representação da cultura muçulmana em esquemas de classificação bibliográfica, considerando as influências da construção do imagético muçulmano no ocidente na escolha terminológica e na construção da estrutura semântica dos assuntos pertinentes a cultura Islâmica nestes esquemas de classificação bibliográfica. Para este fim, aborda-se conceitos básicos sobre o Islamismo, enquanto religião e ideologia, de forma a constituir elementos comuns às comunidades muçulmanas, de forma a fornecer subsídios par identificar incongruências na classificação e na seleção terminológica de assuntos sobre o Islã. 


\section{REPRESENTANDO A IDENTIDADE COLETIVA MUÇULMANA}

A presente seção trata da representação do coletivo muçulmano em esquemas de classificação bibliográfica. Neste sentido, trata-se da questão da influência do contexto sociocultural na representação, observando a construção da imagem do muçulmano pelo Ocidente. Neste sentido, a representação do Islã nos Esquemas de Classificação Bibliográfica tem profunda relação com a construção de sua imagem pelo Ocidente, onde seleciona-se quais informações são dissemináveis, tanto para propagação quanto ao censura de determinada posição. Tal estratégia, também utilizada na construção da identidade coletiva, baseia-se em uma complexa seleção de ideias que quase sempre representam apenas uma fração de um determinado assunto complexo.

Tal composição reducionista de determinada comunidade busca a vulgarização de um ponto de vista, de uma imagem muitas vezes distorcida de determinado assunto. Assim sendo, ao analisar o discurso sobre o Islamismo no Ocidente, identificamos desde o Iluminismo uma construção sobre a composição étnica do Islamismo, associada principalmente a cultura árabe. Tal associação reducionista ignora elementos diversos inerentes à própria religião e os condicionantes locais das diversas comunidades, que influenciam o tanto o relacionamento interno quanto a relação entre crentes e integrantes de outras religiões.

Actualmente, o Islão é definido negativamente como aquilo com que o Ocidente está em confronto radical e esta tensão cria um quadro de entendimento que limita em extremo o conhecimento do Islão. Enquanto este quadro se mantiver, o Islão, enquanto realidade elementarmente vivida pelos muçulmanos, não poderá ser objecto de conhecimento (SAID; 1981, p. 155 apud VAKIL; 2004, p. 17).

O reducionismo inerente à abordagem ocidental sobre Islã constrói a imagem do "Islã Problema", realocando-o ora como questão de segunda classe, ora como ameaça, ignorando a complexidade das discussões inseridas em sua comunidade. Entre as flagrantes manipulações identificáveis na imagem construída do Islão está em sua associação quase que exclusiva à cultura árabe, estabelecendo uma identidade étnica, desconsiderando a conceituação corânica de ummah enquanto comunidade islâmica universal. Contudo, a expressão de uma identidade islâmica abrange assuntos muito mais complexos que sua mera concepção étnica ou religiosa. O Islã envolve debates tanto acerca de suas religiosidades quanto de seu escopo políticolegislativo. Vakil (2004) afirma que:

A imputação simplista da teocracia islâmica, esbatendo a própria diversidade de percursos históricos, compromissos e soluções da relação Estado-Igreja no Ocidente, e cega às expressões de religiosidade pública dos contextos não ocidentais em que vive a larga maioria das populações do globo, não apenas ignora os debates sobre os 
sentidos "islâmicos" e a realidade histórica da relação entre política e religião (Ayub, 1991: 5; Asad, 1993: 200-236, 2003; Ramadan, 2004: 144-47) como as próprias propostas de "secularismo islâmico" (Ezzat e Abdalla, 2004 apud VAKIL, 2004, p. 19).

Figura 2. Campanha Not in My Name - O Islã não é só árabe e não é ISIS

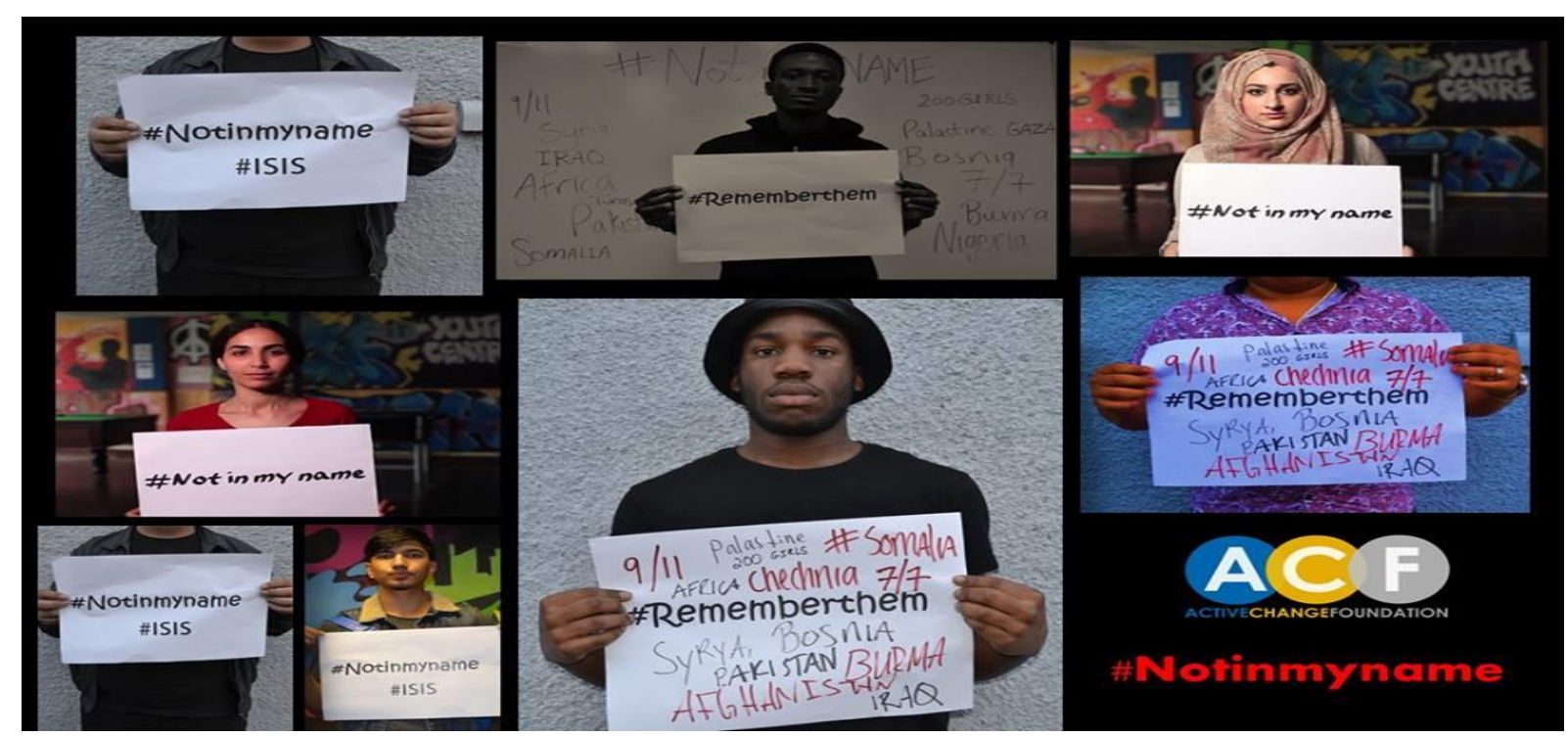

Fonte: Razões para Acreditar (2018).

Esta seção busca demonstrar a complexidade do Islã. Trabalhamos com conceitos relativos ao Islamismo como religião institucionalizada e como ideologia. Identifica-se sua comunidade religiosa e a influência de características socioculturais na formação de uma identidade ao mesmo tempo una e diversificada. Localiza-se o Islã cronológica e geograficamente, e as consequentes transformações nos usos e sentidos dos conceitos referentes ao Islã, caracterizada nas prescrições dispostas na primeira comunidade idealizada por Muhammad e da construção de um identitário muçulmano diversificado, característica inerente ao Islã atual.

Este artigo não visa aprofundar as discussões sobre o Islã, mas investigar certos desvios associados a produção do conhecimento sobre o Islã, muitos destes evidenciados na história dos usos e sentidos dos conceitos relativos a identidade islâmica.

\subsection{O Islã ou Islamismo?}

Segundo Mantran (1977), a partir da Hégira, a religiosidade islâmica comportara disposições de caráter social e político. Duarte (2015), considera a comunidade islâmica aborda questões de um ativismo religioso, onde não existe diferenciação entre o escopo social e o religioso. Por outro lado, Fierro (1997), propõe uma diferenciação entre os termos Islã e Islamismo. Para a autora, Islã é o termo referente à religião dos muçulmanos, correspondendo aos termos Judaísmo e Cristianismo. Designa também a cultura difundida por todo Oriente 
Médio, Norte da África, Ásia e Índia. A esta difusão acompanha-se a língua da revelação, o árabe, a exceção do Irã, um pais muçulmano de língua persa.

Duarte (2015) denota ao Islamismo uma terceira via de conotação ideológica, onde seus aderentes "têm como premissa base a indivisibilidade absoluta da já referida trindade islâmica: o Islão como religião (din), como modo de vida (dunya) e como fórmula governativa (dawla)" (DUARTE, 2015, p. 104). Dentro desta formula, o Islamismo é visto como um movimento social (ortopraxia): não se tratando de uma "formula abstrata de manifestação de fé, nem um excesso de Islão (religiosidade). É um movimento que, como outro movimento social e político análogo, têm uma determinada doutrina, aplica-a ideologicamente e recorre a formas de ação específicas para fazê-la vingar" (DUARTE, 2015, p. 100). Em qualquer das concepções referidas, o Islamismo tem toda sua conduta baseada no componente religioso. Neste ponto:

[a ideologia islâmica se] assenta num vinculo ético que une as pessoas que fazem parte
da mesma sociedade, neste caso, a Ummah. E sendo um movimento de caráter
religioso, a ideologia que o fundamenta parte da ideia de uma comunidade política
(ainda que virtual) peculiar, pois é fruto de um pacto superior as relações contingentes
e precárias do quotidiano da polis. Isto significa que se dá a religião uma função de
integração social e politica, passando a ser a trava mestra da orientação da ação dos
indivíduos em todos os campos da sociedade. (DUARTE, 2015, p. 103)

A Ummah funciona como uma identidade coletiva "desenvolvida no processo social quando indivíduos internalizam valores, alvos e propósitos da sociedade" (HASSAN, 2002, p. 96 apud SANTOS, 2011, p.181). Na Ummah as identidades se entrelaçam ao compartilharem o mesmo mito de origem, os mesmos rituais e os mesmos valores descritos na Sunnah e no Corão.

\footnotetext{
A ummah se tornou uma estrutura onde outras identidades se uniram formando uma só identidade religiosa. Em Medina foi estabelecido um novo meio de coesão social entre os seguidores do Islã, pois, agora eles eram membros de uma comunidade em que havia consciência de identidade que transcendia as outras formas de pertença. A única restrição que havia para a comunidade dos muçulmanos era a fé, assim, os fundamentos para uma religião universal estavam estabelecidos (SANTOS, 2011, p, 168).
}

Santos (2011) reitera a influência da historicidade enquanto mito de origem em uma identidade religiosa. Logo, ao evocar um sentimento de estabilidade, a "história se torna um dos fundamentos para uma noção de identidade. Por isso, existe uma busca para explicar a identidade recorrendo ao passado para que uma legitimidade histórica seja estabelecida" (SANTOS, 2011, p.168). Neste processo, a visão de mundo é orientada segundo a visão do grupo específico objetificando um lugar e personagens históricos ideais, na qual valores e sentidos são corroborados. No caso do Islã, a Medina dos primeiros anos do Islã abrigava a comunidade ideal bem como o homem perfeito. 
Assim, a análise da vida de Muhammad ganha importância na medida em que o profeta como personagem histórico-mítico, na concepção islâmica, traz consigo o modelo perfeito de homem muçulmano e a primeira comunidade considerada como ideal e referência para todas as gerações posteriores de muçulmanos (SANTOS, 2011, p. 169).

A visão deste Muhammad, ao mesmo tempo histórico e mítico para a sociedade islâmica, representava uma ruptura com a sociedade pré-islâmica, cuja organização política era fundamentada segundo tradições familiares, e a organização religiosa sobre uma cultura politeísta. Muhammad organizou uma nova religião e uma nova sociedade, designando os preceitos religiosos e sociais a partir das revelações descritas no Alcorão. Desta forma, o credo muçulmano surge como fator integrativo no desenvolvimento de uma identidade muçulmana. Assim sendo, a próxima seção trata da doutrina religiosa do Islã como componente integrador na comunidade muçulmana.

\subsection{O Islã e o Muçulmano}

Para um muçulmano a vida social começa e termina no Corão. Seus ensinos foram estabelecidos como parâmetro de toda sociedade muçulmana, seja em questões de governo, seja por questões religiosas. Massignon, citado por Mantran (1977) descreve o Corão como fonte de magistério legislativo (amr), magistério judiciário (fiqh) e ao poder executivo. Estabelecido em definitivo por volta do ano 633 durante o califado de Otman "é dividido em 114 suras, com número variável de versículos (aya)" (MANTRAN, 1977, p. 72). Contudo, a medida que a sociedade muçulmana se desenvolvia:

Os muçulmanos não tardaram em verificar que Corão não respondia a todas as questões que surgiram no plano da organização governamental, administrativa e judiciaria; era preciso, então, encontrar complementos que, embora não tirados do Corão, fossem assim mesmo aceito pelos muçulmanos. Estes complementos vieram a constituir a Sunnah, e em nada afetavam a fé (iman) cujo credo integral está no Corão. (MANTRAN, 1977, p. 181).

A Sunnah nada mais é que uma coleção de hadith (tradição) que consistiam nos ditos do profeta Muhammad reunidos pelos seus companheiros. Sua principal função era servir de suporte aos casos não contemplados pelo Corão. Com o tempo a Sunnah enriqueceu-se a tal ponto que foi necessário introduzir uma ciência crítica dos hadiths para distinguir as autenticas das apócrifas (MANTRAN, 1977, p.181). "Do corão e da Sunnah procedeu a Sharia, a lei religiosa que, por sua vez, originou o direito muçulmano. Mas a instituição desse direito e as interpretações da lei deram origem a escolas diversas, ortodoxas ou não, que tiveram influência no poder político e em sua aceitação. (MANTRAN, 1977, p.183). Apesar da crescente 
importância da Sunnah no cotidiano do crente, a mesma não sobrepujava, mas esclarecia o Corão. Contudo, diferenças e divergências da tradição nas diferentes comunidades islâmicas como os sunitas, xiitas e khadjiritas deram origem a uma diversidade de seitas, cada qual dando interpretações religiosas ou filosóficas, baseando-se em elementos por vezes incontroláveis (MANTRAN, 1977, p.184).

Muhammad constantemente afirmava que o Islã não se trata de uma nova fé. Afirmava que a revelação registrada no Corão restabelecia em sua pureza original a religião revelada por Deus a Abraão e que este transmitira a Ismael (MANTRAN, 1977). Seuconteúdo (Iman) era extremamente simples. O princípio essencial era a crença em Alá, Deus único, todo poderoso e eterno, criador de todas as coisas; a crença em Alá é acompanhada da crença nos profetas - o último dos quais foi Muhammad - nos anjos, nos Livros revelados - o ultimo e único necessário dos quais é o Corão -, no dia da ressurreição, na predestinação (qadar), o que implica na negação de liberdade do homem (MANTRAN, 1977, p.72). Quanto a sua estrutura doutrinal, possui como princípios basilares a profissão de fé (Shahada), a oração (Salah), a esmola (Zakat), o jejum no mês do Ramadã (Salat) e a peregrinação (Hajj). Seguindo tais práticas, ensinadas por Muhammad desde o princípio, "será considerado Muslim, que segue a Religião da Verdade (din al-haqq)" (MANTRAN, 1977, p. 72).

A estas obrigações/prescrições acima se costuma acrescentar a Jihad. FIERRO (1997), denota ao termo um duplo sentido: o primeiro relacionado a jihad da alma, na qual denota o esforço espiritual do fiel em seu interior para aperfeiçoar-se no ponto de vista moral e religioso; o segundo um jihad da mão, que remonta ao significado popular e belicista, amplamente divulgado pelo Ocidente e ideologicamente associado a grupos fundamentalistas. A este significado, Fierro (1997) associa o sentido de guerra legal, por se tratar de uma ação armada legal desde o ponto de vista jurídico (FIERRO, 1997, 87). Neste sentido, o objetivo original da jihad não consistia na conversão forçada ou a expansão de fronteiras, mas consistia em uma atitude de defesa, de autopreservação. Mantran (1977), afirma ainda que a jihad representava uma obrigação ocasional, não fazendo parte dos princípios essenciais do Islã. Contudo, muitos estudiosos associam a obrigatoriedade da guerra santa restrita ao contexto específico da pregação do Profeta (MANTRAN, 1977). No entanto, os governos subsequentes à morte do profeta aproveitaram-se do conceito, utilizando-o como forma de propagação do Islamismo (no sentido de estado) para além das fronteiras árabes. Vale considerar que os povos conquistados não eram obrigados a seguir a religião, mas deveriam pagar um imposto de proteção (Dhimmi).

Quanto à adesão (Dawa), Duarte (2014), afirma que estava implícito que toda a comunidade tem a obrigação de expandir o Islã. Para um muçulmano, o "mundo encontra-se 
dividido entre dar al-islam (território islâmico, onde é aplicada a jurisprudência islâmica) e dar al-harb (significa literalmente a morada da guerra, mas refere-se ao território não-islâmico)". Seu objetivo é expandir o dar al-islam pelo mundo inteiro, para que todos possam partilhar de uma ordem social e politicamente justa" (DUARTE, 2014). A atualidade ainda prescreve uma terceira via, onde o muçulmano vive em acordo com o grupo majoritário dos países em que se constitui como minoria. A figura 3 demonstra a atual distribuição dos adeptos no mundo.

Figura 3. Muçulmanos no Mundo

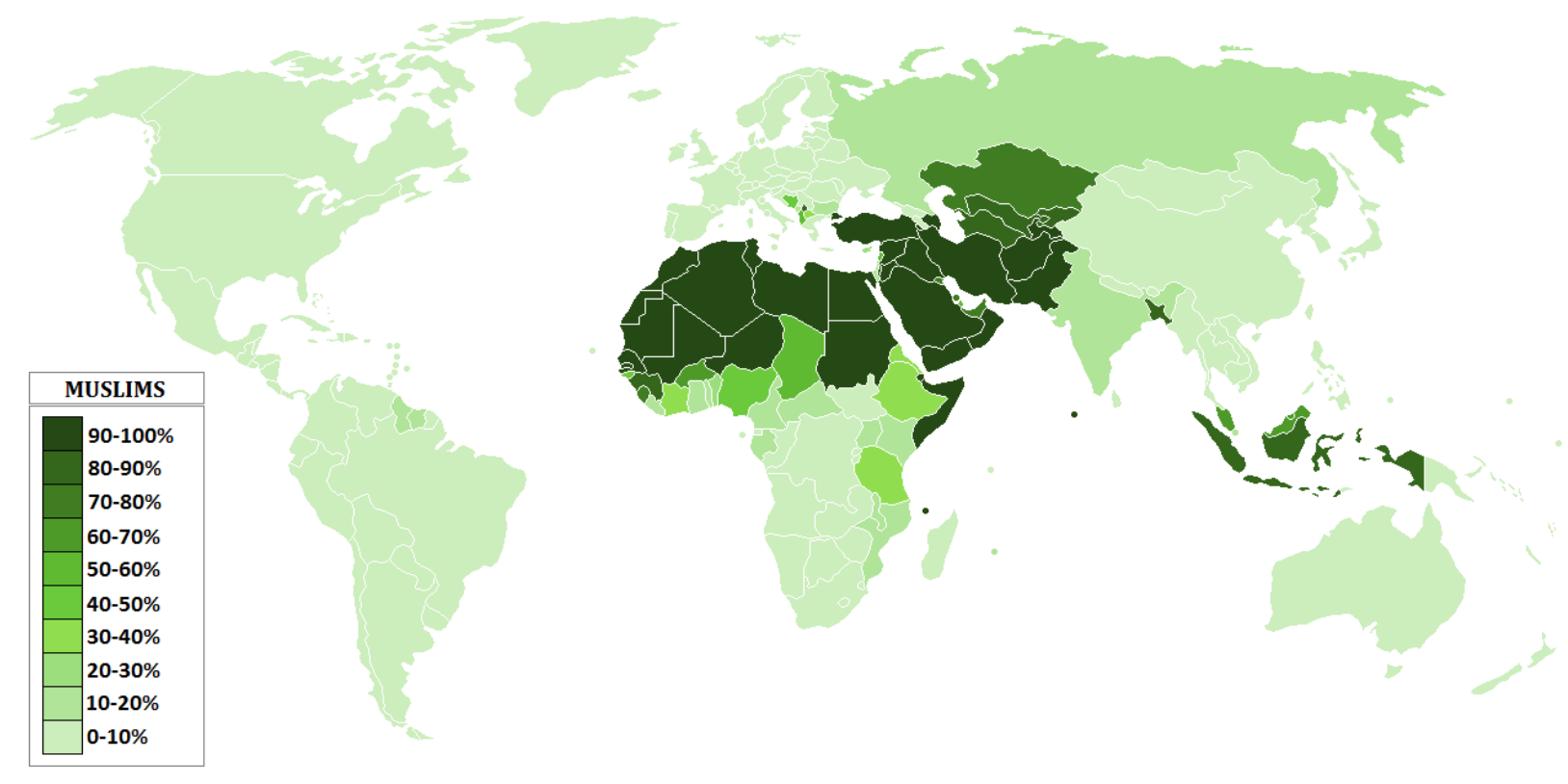

Fonte: WIKIPEDIA (2018).

A comunidade islâmica atualmente compõe cerca de $20 \%$ da população no mundo estando presente em todos os continentes. Sua comunidade possui condição majoritária nos países do norte da África, Oriente médio e parte da Ásia, Europa e Oceania (Figura 1), sendo a segunda em adeptos no mundo, com população significativa em países do primeiro mundo nos Estados Unidos, França, Espanha e etc. No Brasil, segundo o IBGE (2010), são de cerca de 35.671 adeptos. Contudo, as novas composições sociais, advindas principalmente da Diáspora Africana e da crise da Síria, devem compor diversas inserções, tanto nos números quanto nas características do Islã no Brasil. Mesmo assim, os critérios sobre a composição da religião muçulmana pelo IBGE assumem a ideia de auto reconhecimento, da forma em que o muçulmano se vê e constrói sua identidade individual.

A atual composição do Islamismo no mundo sofre a influência de uma série de contextos, que hora evidencia a criação da comunidade unificada por força de seus valores e tradições religiosas, ora denota uma complexa composição ideológica, demonstrada na 
diversidade de ideias circulantes na mesma comunidade. De fato, uma análise estrutural do Islã atual não deve desconsiderar as influências históricas e sociais na construção das várias identidades recorrentes em sua comunidade. Neste sentido, a construção identitária do Islã sunita do Brasil envolve debates intensos, como as interpretações do Corão e da Hadith, da diversidade de seitas e grupos, sobre o lugar da língua árabe, da diversidade étnica dos adeptos do Rio de janeiro, dos arabismos dos adeptos da comunidade de São Paulo e do Paraná; do lugar da violência, da exposição midiática, dos silêncios e da estigmatização de seus costumes e de sua identidade.

A seguir, analisamos como os assuntos referentes a cultura/identidade muçulmana estão representados na CDD23 com o objetivo de investigar como assuntos referentes a identidade muçulmana estão organizados, observando critérios referentes a sua estrutura e seleção terminológica.

\section{ANÁLISE DA REPRESENTAÇÃO DO ISLAMISMO NA CDD}

Nesta seção apresentamos a análise dos resultados alcançados pela nossa pesquisa no que se refere à representação do Islamismo na CDD23. O levantamento terminológico sobre informações acerca do Islamismo realizou-se no WebDewey.

Os assuntos referentes ao Islamismo estão representados na CDD23 sob as seguintes notações:

a) 297 - Islamismo, Babismo e Fé Bahai - informações referentes às bases da Religião Islâmica estão dispostas sob as notações 297.1 - 297.8

b) Classe 300 - Ciências Sociais. Informações/ materiais sobre direito Islâmico (Shariah) são classificados sob a notação 340.59 - Sistemas legais religiosos, em relação de subordinação a classe 340.5 - sistemas legais.

c) Classe 700 - Artes e Recreação. Notações referentes às representações artísticas sobre o Islã estão sob as notações: 700.48297 - Arte islâmica; $704.94897 \quad$ - Islã Representação Artística; 704.9489735 - Lugares sagrados-Islã - Representações Artísticas; 704.948974092 - Santos (Sufi)--Representações artísticas;

d) Classe 800 - Literatura. Notações referentes às obras literárias sobre o Islã estão sob as notações:

$\begin{array}{ll}808.8038297082 & \text { Mulher--Religião--Islã-Literatura; } \\ 808.803829761 & \text { Líderes Religiosos - Islã -literatura - coleções; }\end{array}$


809.9338297082 Mulher--Religião--Islã-Literatura- História e Critica; 809.933829761 Mulher--Religião--Islã-Literatura-historia e crítica.

e) Classe 900 - História e Geografia. A biografia de Adeptos do Islã é subordinada a classe 920: Biografias e está representada sob a notação 922(.97).

Quanto a estrutura conceitual, compara-se a abordagem classificatória em relação a outras religiões, observando critérios como ordenação lógica, usos e sentidos implícitos nas relações entre os conceitos e detalhamento de assuntos dentro da estrutura conceitual.

Em relação a ordenação lógica de assuntos, a análise da estrutura da CDD apresenta como resultados:

a) As diferentes concepções de Deus, (caso de Deus segundo o Cristianismo e Deus segundo o Islamismo) estão em classes de níveis hierárquicos diferentes.

b) Textos de maior autoridade das religiões são dispostos em classes de nível hierárquico diferentes, evidenciando a maior visibilidade ao Cristianismo. A Bíblia na CDD ocupa a classe principal 220 e o Alcorão e o Hadith ocupam a notação 297.122.

c) A própria existência da classe Outras Religiões - 290, considerando como religiões não-cristãs.

d) As diferentes concepções de SEITA (SECTS) no Cristianismo e no Islamismo. Seita, para os Cristãos, entende-se como "Grupo religioso dissidente, que deixa de participar de uma religião por não concordar com suas normas e objetivo" (Dicionário Online de Português) e no Islamismo é considerada como divisões (setores) de uma mesma religião. Outro aspecto é a disposição em uma mesma classe de palavras que se referem à Seitas e Movimentos Reformadores.

e) A correlação entre as religiões ISLAMISMO, BABISMO e FÉ Ba'hai, em relação de coordenação, e SUFISMO como subdivisão do ISLAMISMO.

Quanto a análise de usos e sentidos implícitos na Classificação Decimal de Dewey, os resultados obtidos foram:

a) Documenos sobre a Jihad estão representados sob a notação 297.72, em relação de subordinação a classe 297.7 - Proteção e propagação do Islã. Conforme visto em seção anterior, a ideia de Jihad por Mantran (1977) envolve um duplo sentido. A abordagem belicista dos primeiros anos do Islã e abordagem espiritual acerca da preservação da fé de modo individual. A ideia implícita de uma Jihad para a conversão forçada nunca foi uma unanimidade no Islã. De fato, estruturar a Jihad como uma forma de propagação ou proteção da fé trata-se de um reducionismo inerente da construção do discurso Ocidental sobre o Islã. 
b) As classes Adoração Islâmica e Adoração Sufi. A adoção do termo Adoração para simbolizar práticas e preceitos religiosos aborda somente parte da vida religiosa do muçulmano. Mais do que formas de adoração, as práticas religiosas, preceitos e pilares do Islamismo são uma forma de expressão dos valores e da identidade do muçulmano. Desta forma, novamente lida-se com o reducionismo na forma de considerar os assuntos sobre a vida religiosa do Islã.

c) A classe 297.8 - Seitas islâmicas e movimentos reformadores. A classificação do Islamismo Sunita e Xiita juntamente com os demais movimentos e seitas sugere o desconhecimento da natureza de cada setor do Islã. Além disso, notações referentes ao Islamismo Ibadista ocupam menor espaço em relação as demais. Ausência sentida está em notações sobre partidos políticos islamicos como Hamás, Irmandade Muçulmana e o Partido da Justiça e Desenvolvimento de Marrocos.

d) Os pilares do Islã são: Confissão de Fé (Shahada), oração(Salah), a esmola (Zakat) o jejum no mês do Ramadã (Salat) e a peregrinação a Meca (Hajj). Contudo, os termos não estão submissos a notação Pilares do Islã (297.31), estão dispersas sob as notações 297.3524 (Hajj), 297.3822 (Salat), 297.54 (Zakat), 297.34 (Shahada) e 297.362 (Sawn Ramadan).

$\mathrm{Na}$ análise CDD23, observando a possibilidade de detalhamento de assuntos, chegamos aos seguintes resultados:

a) Problemas com a hospitalidade de assuntos. A rigidez do sistema enumerativo e hierárquico impõe dificuldades na composição de notação de assuntos complexos. No caso do Islã, novos conhecimentos são frequentemente relegados a uma sub-representação, na qual o profissional decide por uma redução nos sentidos referentes ao assunto representado.

b) A maior visibilidade da abrangência de assuntos relativos ao Cristianismo, evidenciada nas Classes Filosofia e Teoria da Religião; A Bíblia e Religiões específicas e Cristandades. Neste sentido, observa-se a histórica tendência a cosmovisão cristã, na Classe 200 Religião, que possui maior abrangência em comparação com outras religiões.

Ao analisarmos a CDD23 também observamos que a seleção terminológica, cuja estrutura apresenta o termo mais conhecido e sua tradução entre parênteses, estabelece uma aproximação com as expressões utilizadas pela comunidade representada. Neste sentido, os termos apresentados podem ter influenciado na escolha da CDD23 por bibliotecas com vastas coleções da cultura Islâmica. A adequação terminológica só não é total devido às diversas transformações de sentido demonstrados na estruturação dos conceitos referentes à religião e a cultura Islâmica. Outros problemas de adequação também foram identificados emnossa análise: 
a) Dispersão das notações referentes ao Islamismo.

b) Reducionismo implícito na disponibilização de classes referentes ao Islamismo.

c) Ambiguidade na representação de termos referentes a legislação Islâmica.

Quanto às atualizações da classe religião na $\mathrm{CDD}$, reconhecemos que a mesma não apresentou resultados práticos, por não se tratar em uma transformação na forma de classificação. Houve apenas uma nova apresentação sistematizada, sem mudanças na abordagem classificatória, sem transformações na terminologia ou na estrutura classificatória.

Quanto a seleção terminológica, as atualizações de vocabulário na classe Religião, conferem a CDD uma linguagem imparcial, própria de um SOC que se diz universal. O problema consiste nas próprias noções acerca da religiosidade, cuja linguagem não reconhece os sentidos inerentes a cada religião abordada. Alguns problemas de linguagem reconhecidos são referidos as noções de Deus, deuses e seres espirituais que, dependendo da religião ou cultura abordada, deveriam obter representações diferentes na sua estrutura hierárquica, além do que apresenta um enviesamento à ideologia cristã, a representandouma visão de fora de uma comunidade com uma diversidade de questões/assuntos que interferem diretamente na construção de sua identidade.

\section{CONSIDERAÇÕES FINAIS}

A representação do conhecimento em religiões envolve uma série de questões de fundo cultural e ideológico, que influenciam tanto a estrutura quanto a seleção conceitual em um esquema de classificação bibliográfica. A CDD é um dos esquemas de classificação mais utilizados no mundo e sua construção é produto de um contexto sociocultural do ocidente, o que infere um enviesamento de assuntos que são externos à nossa cultura ocidental.

Verificamos preconceitos acerca de determinadas religiões, identificáveis quanto a ordenação, vocabulário ou detalhamento de assuntos referentes a religião não favorecida na CDD23. O viés em instrumentos de classificação, sua concepção e na formação cultural interfere de forma direta o trabalho do classificacionista e do classificador, orientando tanto a seleção terminológica quanto sua localização na estrutura classificatória.

Como resultado, observamos a reprodução de desvios históricos como: ausência de atualização sobre assuntos emergentes ao conhecimento muçulmano; dificuldade na representação de assuntos complexos; o enviesamento a cosmovisão judaico-cristã Ocidental; evidente discurso majoritário expresso na estrutura hierárquica da CDD. 
Os resultados da pesquisa confirmam que contextos socioculturais da criação dos esquemas de classificação bibliográfica orientam diretamente a representação de assuntos considerados marginais a cultura ocidental. No caso do Islamismo, as evidencias corroboram uma produção bibliográfica que adota usos e sentidos próprios da cultura ocidental e repletos de incorreções de significado acerca da cultura e da identidade muçulmana. Assim, tanto a produção bibliográfica, utilizada como garantia de seleção terminológica, quanto a estrutura reproduzem um discurso estigmatizado ou desatualizado sobre o conhecimento muçulmano em geral.

Vale considerar que a estrutura facetada confere maiores e melhores possibilidades de representação, uma vez que a estrutura de sua notação confere maior hospitalidade de assuntos diferente do que ocorre na CDD.

As características evidenciadas nas composições do identitário muçulmano tornam-se um desafio para o classificador, uma vez que esquemas de classificação bibliográficos da atualidade não fornecem subsídios suficientes para a organização minuciosa de uma rica coleção da cultura muçulmana. Dos diversos prejuízos causados por uma sub-representação, destaca-se a transferência da responsabilidade pela disseminação do conhecimento islâmico a uma estrutura informacional enviesada por valores e culturas ocidentais, interferindo diretamente nos usos e sentidos das expressões referentes a cultura muçulmana. Exemplo repetido ao longo do artigo é a associação entre os termos fundamentalismo, jihad e terrorismo em diversos veículos de mídia ocidental; e a opção pelo termo "Estado Islâmico" ao se referir ao grupo terrorista ISIS.

Vale considerar que a representação da cultura islâmica na CDD sofre diversas atualizações como forma de reduzir o enviesamento pela cultura judaico cristã. Contudo, observa-se também a reincidência de problemas históricos de estrutura, onde se evidencia o discurso da criação do esquema, impondo dificuldades a bibliotecários classificadores de coleções ricas em cultura muçulmana.

A pesquisa não se propôs a responder sobre os motivos do enviesamento na classificação e representação do conhecimento muçulmano. A intenção era estabelecer um novo olhar, a partir do reconhecimento ao direito a expressão da identidade e da propagação da visão de mundo plural, considerando tanto as especificidades das comunidades locais, quanto as necessidades de reconhecimento de uma comunidade global.

Como proposta de pesquisas futura, verificamos a possibilidade de umestudo sobre as influências da seleção conceitual nos usos e sentidos do termo, considerando sua atuação na 
construção de discursos ou na desconstrução de verdades históricas a partir da disseminação da informação em mídias sociais e veículos de mídia tradicional. 


\section{REFERENCIAS}

AHJUM, Gadija. Re-constructing a religious identity through activism in an Islamist movement: experiences of female members of Qibla. Journal for Islamic Studies, v. 33, n. 1, p. 151-184, 2013. Disponível em: https://idslide.net/view-doc.html?utm_source=reconstructing-a-religious-identity-through-activism-in-an-islamist-movement-experiences-offemale-members-of-qibla. Acesso em: $01 \mathrm{dez} 2018$.

ARBOIT, Aline Elis. Representação do conhecimento como ato ideológico. Logeion: Filosofia da Informação, Rio de Janeiro, v. 4, n. 1, p. 154-166, 2017. Disponivel em: http://revista.ibict.br/fiinf/article/view/4129/3483. Acesso em: 1 nov 2018.

AZEVEDO, Cristiane. A procura do conceito de Religio: entre o relegere e o religare. Religare: Revista do Programa de Pós-Graduação em Ciências das Religiões da UFPB, Paraíba, v. 7, n. 1, 2010. Disponível em:

http://www.periodicos.ufpb.br/ojs/index.php/religare/article/view/9773/5351. Acesso em: 01 Dez 2018.

BARITÉ, Mario. La garantía cultural como justificación en sistemas de organización del conocimiento: aproximación crítica. Palabra clave, Montevideo,v. 1, n. 1, p. 02-11, 2011. Disponível em: http://www.scielo.org.ar/scielo.php?script=sci_arttext\&pid=S185399122011000200002\&lng=es\&nrm=iso. Acessado em: 11 nov 2018.

BARITÉ, Mario et al. Garantia literária: elementos para uma revisão crítica após um século. TransInformação, Campinas: v. 22, n. 2, 2010. Disponível em: https://www.redalyc.org/pdf/3843/384334884003.pdf. Acesso em 11 nov 2018

BERLATTO, Odir. A construção da identidade social. Revista do Curso de Direito da Faculdade da Serra Gaúcha, Caxias do Sul: n. 5, 2009. Disponível em: ojs.fsg.br/index.php/direito/article/viewFile/242/210. Acesso em: $01 \mathrm{dez} 2018$

BRASIL. Presidência da República. Decreto no 592, de 6 de julho de 1992. Pacto Internacional sobre Direitos Civis e Políticos.

BROUGHTON, Vanda. A new classfication for the literature of religion. International cataloguing and bibliographic control, Jerusalem, v. 4, n. 29, p. 59-61, 2000. Disponível em: http://archive.ifla.org/IV/ifla66/papers/034-130e.htm. Acesso em: $01 \mathrm{dez} 2018$.

BROUGHTON, Vanda. Concepts and Terms in the Faceted Classification: the Case of UDC. Knowledge organization, Frankfurt, v. 37, n. 4, 2010. Disponível em: http://searchebscohost-com.ez39.periodicos.capes.gov.br/login.aspx? direct=true \&db=iih\&AN=55666964\&lang=pt-br\&site=ehost-live. Acesso em 20 nov. 18

CAFÉ, Ligia Maria Arruda; BRÄSCHER, Marisa. Organização da informação e bibliometria. Encontros Bibli: revista eletrônica de biblioteconomia e ciência da informação, Florianópolis, p. 54-75, jan. 2008. ISSN 1518-2924. Disponível em: 
https://periodicos.ufsc.br/index.php/eb/article/view/1518-2924.2008v13nesp1p54/1032. 28 nov. 2018. doi:https://doi.org/10.5007/1518-2924.2008v13nesp1p54

COUTINHO, José Pereira. Religião e outros conceitos. Sociologia, Porto, v. 24, p. 171-193, 2012. Disponível em: http://ler.letras.up.pt/uploads/ficheiros/10763.pdf. Acesso em: 28 nov. 2018.

DAHLBERG, Ingetraut. Teoria do conceito. Ciência da Informação, Rio de Janeiro, v. 7, n. 2, dec. 1978. ISSN 1518-8353. Disponível em: http://revista.ibict.br/ciinf/article/view/115. 16 mal 2017. doi:http://dx.doi.org/10.18225/ci.inf.v7i2.115.

DAHLBERG, I. Current Trends in Knowledge Organization. In: GARCÍA MARCO, Fco. Javier (Ed.). Organización del Conocimiento en sistemas de información y documentación. Zaragoza: ISKO - España, 1995. p. 7-25.

DAHLBERG, I. Knowledge organization: a new science? Knowledge organization, [S.1.], v. 33 , n. 1, 2006.

DUARTE, Felipe Pathé. O islamismo como ideologia política de carácter secular. Relações Internacionais, Lisboa, n. 45, p. 97-110, mar. 2015. Disponível em: http://www.scielo.mec.pt/scielo.php?script=sci_arttext\&pid=S164591992015000100006\&lng=pt\&nrm=iso. Acesso em 13 Out. 2018.

FIERRO, Maribel. Islamismo. Scripta Fulgentina: revista de teología y humanidades, 1997, v. 7, n. 13, p. 81-93. Disponível em: http://institutosanfulgencio.es/scripta-fulgentina. Acesso em 11 out. 2018 .

GUERRIERO, Silas. A atualidade da teoria da religião de Durkheim e sua aplicabilidade no estudo das novas espiritualidades. Estudos de Religião, [S.1.], v. 26, n. 42, p. 11-26, 2012. Disponível em: https://www.metodista.br/revistas/revistasims/index.php/ER/article/view/3409/3210. Acesso em: 18 nov 2018.

GUIMARÃES, José Augusto Chaves. A dimensão teórica do tratamento temático da informação e suas interlocuções com o universo científico da International Society for Knowledge Organization (ISKO). Revista Ibero-Americana de Ciência da Informação, [S.1.], v. 1, n.

1, fev. 2011. Disponível em: http://periodicos.unb.br/index.php/RICI/article/view/2761. Acesso em: 17 maio 2017.

HJORLAND, Birger. Fundamentals of Knowledge Organization (KO). Knowl. Org. Copenhagen, 30, n. 2, 2003. Disponivel em:

http://ppggoc.eci.ufmg.br/downloads/bibliografia/Hjorland2003.pdf. Acesso em: 18 out. 2018 
HJORLAND, Birger. What is Knowledge Organization (KO)? Knowl. Org., Copenhagen, v. 35, n. 2/3, 2008. Disponível em:

https://www.researchgate.net/publication/277803483_What_is_Knowledge_Organization_K O. Acesso em: 18 out 2018.

HJORLAND, Birger. Theories of Knowledge Organization - Theories of Knowledge. Knowl. Org. Copenhagen, v. 40, n.3, 2013. Disponível em: http://www.iskode.org/data/uploads/KOAndTheoriesOfKnowlede.pdf. Aceso em: 18 out 2018.

HJORLAND, Birger. Theories are Knowledge Organizing Systems (KOS). Knowledge Organization, [s. 1.], v. 42, n. 2, p. 113-128, 2015. Disponível em: http://search-ebscohostcom.ez39.periodicos.capes.gov.br/login.aspx?direct=true \&db=iih\&AN=103041685\&lang=ptbr\&site=ehost-live. Acesso em: 13 dez. 2018.

HODGE, Gail. Systems of Knowledge Organization for Digital Libraries: Beyond Traditional Authority Files. Digital Library Federation, Council on Library and Information Resources, 1755 Massachusetts Ave., NW, Suite 500, Washington, DC 20036, 2000. Disponível em: https://eric.ed.gov/?id=ED440657. Acesso em: 19 out. 2018.

IBEZIM, Ijeoma G. The challenges of religion and ethnic identity in Nigeria. Journal of Religion and Human Relations, [S.1.], v. 1, n. 6, p. 90-100, 2014. Disponivel em: https://www.ajol.info/index.php/jrhr/article/view/111518/101302. Acesso em: 01.12.2018.

IBGE. Censo Demográfico 2010: Características gerais da população, religião e pessoas com deficiência. Disponível em:

https://ww2.ibge.gov.br/home/estatistica/populacao/censo2010/caracteristicas_religiao_defici encia/caracteristicas_religiao_deficiencia_tab_xls.shtm. Acesso em: 30 nov. 2018.

MANTRAN, Robert. Expansão Muçulmana (séculos vii-xi). São Paulo: Pioneira, 1977.

MIGLIOLI, S.; SANTOS, G. A. Acessibilidade e serviços inclusivos para minorias sociais: a biblioteca do instituto nacional de educação de surdos. Revista ACB: Biblioteconomia em Santa Catarina, Florianópolis, v. 22, n. 1, p. 136-149, 2017. Disponível em:

http://www.brapci.inf.br/index.php/res/download/89330. Acesso em: 01 nov. 2018

MILANI, S. O.; GUIMARÃES, J. A. C. Problemas éticos em representação do conhecimento: uma abordagem teórica. DataGramaZero, Rio de Janeiro, v. 12, n. 1, 2011. Disponível em: http://www.brapci.inf.br/index.php/res/download/45615. Acesso em: 01 nov. 2018

MIRANDA. Marcos Luiz Cavalcanti de. A Organização do etnoconhecimento: A representação do conhecimento afrodescendente em Religião. Revista África e Africanidades, Rio de Janeiro, v. 1, n. 4, p.5, jan. 2009. Disponível em: http://www.africaeafricanidades.com.br/documentos/A_organizacao_do_etnoconhecimen to.pdf. Acesso em: 01 nov. 2018 
MOL, Hans. The Identity Model of Religion: How It Compares with Nine Other Theories of Religion and How It Might Apply to Japan. Japanese Journal of Religious Studies, [S.1.], v. 6, n. /1-2 March-June 1979. Disponível em: https://nirc.nanzan-u.ac.jp/nfile/3052. Acesso em: 01 out 2018.

MOREIRA, Vital; GOMES, Carla De Marcelino (Orgs). Compreender os Direitos Humanos: manual de educação para os direitos humanos. IGC/CDH, Lisboa, 2013.

OLSON, Hope A. A potência do não percebido: Hegel, Dewey e seu lugar na corrente principal do pensamento classificatório. InCID: Revista de Ciência da Informação e Documentação, Ribeirão Preto, v. 2, n. 1, p. 3-15, jun 2011. ISSN 2178-2075. Disponível em: http://www.revistas.usp.br/incid/article/view/42331. Acesso em: 06 out. 2016.

OLSON, H. A. The power to name: locating the limits or subject representation in libraries. Dordrecht: Kluwer Academic Publisher, 2002.

POWELL, Adam J. Functionalism or fallacy: re-locating Hans Mol's identity theory. Italian Sociological Review, [S.1.], v. 70, n. 1, p. 63-85, 2017. Disponível em: http://www.italiansociologicalreview.com/ojs/index.php?journal=ISR\&page=article\&op=vie w\&path\%5B\%5D=149\&path\%5B\%5D=155. Acesso em: 30 nov. 2018.

RAZÕES PARA ACREDITAR. Disponível em: https://razoesparaacreditar.com/wpcontent/uploads/2015/11/Not-in-my-name-campaign.jpg. Acesso em: 01 nov. 2018.

SANTOS, Delano de Jesus Silva. Ummah e narrativas: história e identidade da religião islâmica. PLURA. Revista de Estudos de Religião, vol. 2, nº 1, 2011, p. 167-196. Disponível em: http://www.abhr.org.br/plura/ojs/index.php/plura/article/view/39/pdf_4. Acesso em: 01 de out de 2018.

VAKIL, Abdoolkarim. Pensar o Islão: Questões coloniais, interrogações pós-coloniais. Revista Crítica de Ciências Sociais, n. 69, p. 17-52, 2004.

YAAKUB, M. B. Knowledge Management from Islamic Perspective. Revelation and Science, [S.1.], v. 01, n. 02 (1433H/2011), p. 14-24. Disponível em::

https://www.researchgate.net/publication/268439191_Knowledge_Management_from_Islami c_Perspective Acesso em 28 ago 2018. 